\title{
PROGRAM PENYULUHAN TEKNOLOGI FERMENTASI DEDAK PADI DENGAN MENGUNAKAN PROBIOTIK DI DESA AYUNAN KECAMATAN ABIASEMAL BADUNG
}

\author{
I.K.H.Valentino ${ }^{1}$, I.D.N.A.Purnata ${ }^{2}$, H.Daniel ${ }^{3}$, L.Jasa $^{4}$
}

\begin{abstract}
ABSTRAK
Desa Ayunan merupakan salah satu desa yang berada di Kecamatan Abiansemal-Badung. Desa Ayunan memiliki potensi yang sangat besar di bidang pertanian, sehinggga memiliki potensi yang besar pula dalam mengahasilkan limbah pakan, khususnya dedak padi. Tetapi dedak padi kurang banyak dimanfaatkan sebagai bahan pakan ternak karena teksturnya yang kasar, baunya apek dan tidak disukai oleh ternak, sehingga peternak di Desa Ayunan beralih ke bahan pakan lain dengan cara membeli. Dari permasalahan tersebut, teknologi dalam pengolahan pakan sangat dibutuhkan, salah satunya adalah teknologi fermentasi dedak padi. Adapun tujuan dari penyuluhan ini adalah merubah kebiasaan peternak agar mampu memanfaatkan dedak padi yang lebih memiliki kualitas yang baik dengan nilai gizi yang tinggi sebagai bahan pakan ternak. Pelaksanaan kegiatan dilaksanakan 3 hari di 3 Banjar di Desa Ayunan dengan tingkat keberhasilan $85 \%$. Sedangkan bagi paternak yang belum memahami ilmu yang di sampaikan, maka penyuluhan ulang dilakukan.
\end{abstract}

Kata kunci : Dedak Padi dan Fermentasi

\begin{abstract}
Ayunan village is a village located in District Abiansemal-Badung. Ayunan village has a huge potential in agriculture, so as to have greater potential to result in the waste of food, especially rice bran. But the rice bran is less widely used as animal feed because the rough texture, smell musty and are not liked by cattle, so that farmers in the Ayunan village switch to other feed ingredients by way of purchase. Of these problems, the technology in the processing of feed is needed, one of which is rice bran fermentation technology. The purpose of this extension is to change the habits of farmers to be able to utilize more rice bran have good quality with high nutritional value as animal feed. Implementation of the activities carried out 3 days in 3 Banjar village swing with a success rate of $85 \%$. As for breeder who do not understand the science that is conveyed, then the extension will work.
\end{abstract}

Keywords: Rice bran and Fermentation

\section{PENDAHULUAN}

Desa Ayunan yang terletak di Kecamatan Abiansemal, Kabupaten Badung, memiliki berbagai potensi yang sangat cocok dikembangkan khususnya di bidang pertanian dan peternakan. Desa ini memiliki topografi yang baik mulai dari tanahnya yang subur dan

\footnotetext{
${ }^{1}$ Mahasiswa Fakultas Peternakan UNUD, Denpasar,hendravalentino14@yahoo.com

${ }^{2}$ Mahasiswa Fakultas Kedokteran Hewan UNUD, Denpasar

${ }^{3}$ Mahasiswa PS Teknologi Industri Pertanian, FTP UNUD, Denpasar

${ }^{4}$ Dosen PS Teknik Elektro, FT UNUD, Denpasar
} 
adanya sungai yang membentang di sepanjang desa sehingga memudahkan masyarakatnya untuk bertani. Sudah beberapa pengharagaan yang didapat desa Ayunan khususnya di bidang irigasi pertanian ( subak ). Maka tidaklah heran jika desa ini juga merupakan desa yang subur dengan sumber air yang mencukupi, memiliki hamparan sawah yang sangat luas dan perkebunan yang sangat baik. Sehingga dari potensi pertanian yang besar, maka potensi dari pakan ternak juga besar.

Pakan ternak yang dimaksud adalah pakan ternak yang berasal dari limbah pertanian, bisa berupa jerami, bungkil dan dedak padi. Dari sekian limbah pertanian yang bisa dimanfaatkan sebagai bahan pakan ternak, pemanfaatan dedak padi sebagai pakan ternak adalah yang terendah di Desa Ayunan. Hal ini dikarenakan dedak padi memiliki tektur yang kasar, berbau apek dan jarang disukai oleh ternak sehingga tidak dimanfaatkan oleh peternak.

Selain itu tidak dimanfaatkannya dedak padi sebagai bahan pakan ternak dipengaruhi pula oleh kurangnya pengetahuan masyarakat mengenai kandungan nutrisi dan gizi bahan pakan sehingga para peternak di Desa Ayunan lebih cendrung memilih polard ( dedak gandum ) yang lebih disukai oleh ternak dan cara memperolehnya dengan cara membeli yang menyebabkan tidak maksimalnya keuntungan yang didapat dari hasil beternak. Dari permasalahan tersebut memang sudah saatnya kebiasaan masyarakat dirubah, melalui penyuluhan mengenai pengolahan pakan yang pada kesempatan ini dilaksanakan oleh mahasiswa KKN-PPM Universitas Udayana ke XIII Desa Ayunan (LPPM Unud 2016). Adapun penyuluhan yang diberikan adalah mengenai teknologi fermentasi khususnya untuk fermentasi dedak padi.

Dedak padi merupakan produk hasil ikutan dari penggilingan padi dimana bahan pakan ini banyak digunakan sebagai ransum ternak babi, sapi dan unggas. Keunggulan dedak padi, terutama kaya akan thiamindan sangat tinggi dalam niasin ( Protein kasar 12,9\% ), lemak 13\%. sedangkan kelemahan utama dedak padi sebagai pakan unggas adalah kandungan serat kasarnya yang cukup tinggi 11,4\%, kandungan protein rendah, dan adanya senyawa fitat yang dapat mengikat mineral dan protein. Untuk meningkatkan kualitas kedua bahan 
pakan di atas dilakukan suatu perlakuan yaitu teknik fermentasi dengan menggunakan molasses dan elektif mikroorganiseme lokal sebagai inokulum.

Fermentasi merupakan proses perubahan kimiawi pada substrat organik melalui aksi enzim yang dihasilkan oleh mikroorganisme. Menurut (Sukaryana, 2011), Proses fermentasi dapat meminimalkan pengaruh antinutrisi dan meningkatkan kecernaan bahan pakan dengan kandungan serat kasar tinggi yang ada pada dedak padi. Dengan teknologi fermentasi pakan, dedak padi yang melimpah di Desa Ayunan dapat dimanfaatkan oleh peternak. Sehingga peternak memperoleh keuntungan yang maksimal.

\section{METODE PEMECAHAN MASALAH}

Adapun kendala yang dihadapi dalam pelaksanaan program ini yaitu jumlah probiotik yang terbatas sehingga tidak menjangkau semua peternak serta pada saat melakukan penyuluhan, peternak bersangkutan tidak ada di tempat sehingga peternak tidak memperoleh materi. Fermentasi pakan adalah salah satu cara yan paling tepat untuk dilakukan. Metode yang digunakan dalam menjalankan kegiatan ini adalah penyuluhan secara individu (door to door) yaitu melakukan penyuluhan secara langsung dari satu peternak ke peternak lainnya. Disamping itu, untuk memantapkan program ini kami menambahkan kegiatan pelayanan ternak berupa pemberian vitamin B kompleks kepada ternak babi dan sapi.

Penyuluhan mengenai teknologi fermentasi dedak padi, menggunakan metode perorangan yaitu dengan jalan kunjungan ke rumah-rumah peternak secara langsung. Penyuluhan dilakukan di 3 Banjar di Desa Ayunan yaitu pada tanggal 30 juli 2016 di Br. Badung Tengah, tanggal 31 juli 2016 di Br. Gria dan tanggal 2 Agustus 2016 di Br. Ambengan. Sebelum melakukan penyuluhan, mahasiswa terlebih dahulu melakukan survei peternak yang kiranya potensial diberikan penyuluhan dan membuat AVA ( Audio Visual Aid) atau alat bantu penyuluhan berupa : Dedak padi yang sudah difermentasi, Probiotik Cair, Vit B Kompleks dan spite untuk babi dan sapi. Dengan adanya AVA ( Audio Visual Aid) memudahkan mahasiswa dalam menyampaikan materi penyuluhan, sehingga peternak juga mudah memahaminya. Adapun daftar nama peternak yang memperoleh penyuluhan di Desa Ayunan adalah sebagai berikut : 


\begin{tabular}{|c|c|c|c|c|}
\hline No & Nama Peternak & Alamat & $\begin{array}{c}\text { Jenis } \\
\text { Ternak }\end{array}$ & $\begin{array}{c}\text { Jumlah } \\
\text { Ternak }\end{array}$ \\
\hline \multirow[t]{2}{*}{1} & Ni Nyoman Gandra & Br. Badung Tengah & Babi & 8 ekor \\
\hline & & & Sapi & 5 ekor \\
\hline 2 & I Ketut Petruk & Br. Badung Tengah & Babi & 1 ekor \\
\hline 3 & I Nyoman Dauh & Br. Badung Tengah & Babi & 4 ekor \\
\hline 4 & I Wayan Bagiastrayasa & Br. Badung Tengah & Babi & 1 ekor \\
\hline \multirow[t]{2}{*}{5} & I Wayan Mer & Br. Badung Tengah & Babi & 3 ekor \\
\hline & & & Sapi & 1 ekor \\
\hline \multirow[t]{2}{*}{6} & I Nyoman Muglen & Br. Badung Tengah & Babi & 11 ekor \\
\hline & & & Sapi & 2 ekor \\
\hline \multirow[t]{2}{*}{7} & Ni Ketut Samu & Br. Badung Tengah & Sapi & 1 ekor \\
\hline & & & Babi & 2 ekor \\
\hline \multirow[t]{2}{*}{8} & I Nyoman Rusa & Br. Badung Tengah & Babi & 5 ekor \\
\hline & & & Sapi & 2 ekor \\
\hline 9 & I Ketut Subagia & Br. Gria & Sapi & 1 ekor \\
\hline \multirow[t]{2}{*}{10} & I Ketut Kacir & Br. Gria & Sapi & 1 ekor \\
\hline & & & Babi & 4 ekor \\
\hline 11 & I Made Buktiyasa & Br. Gria & Sapi & 1 ekor \\
\hline 12 & I Ketut Suratna & Br. Gria & Sapi & 1 ekor \\
\hline 13 & I Ketut Molog & Br. Gria & Babi & 1 ekor \\
\hline 14 & I Nyoman Muliarsa & Br. Gria & Babi & 6 ekor \\
\hline \multirow[t]{2}{*}{15} & I Nyoman Purna & Br Ambengan & Babi & 6 ekor \\
\hline & & & Sapi & 2 ekor \\
\hline \multirow[t]{2}{*}{16} & I Made Karmawan & Br. Ambengan & Sapi & 2 ekor \\
\hline & & & Babi & 4 ekor \\
\hline
\end{tabular}

(Sumber : Program Peningkatan Produksi KKN-PPM UNUD 2016 Desa Ayunan )

Dari data di atas jumlah babi 54 ekor dan jumlah sapi 19 ekor jumlah ternak tersebut mewakili dari masing-masing banjar kecuali Br. Badung karena populasi dari ternaknya paling sedikit dari banjar-banjar lainnya di Desa Ayunan. Selain memberikan penyuluhan 
mengenai fermentasi dedak padi, mahasiswa juga memberikan kegiatan tambahan berupa pelayanan ternak yaitu memberikan vitamin B kompleks.

\section{HASIL DAN PEMBAHASAN}

Dari hasil metode penyuluhan perorangan yang dilakukan yang melibatkan peternakpeternak potensial di Desa Ayunan diperoleh hasil dengan keberhasilan $85 \%$. Keberhasilan tersebut dilihat dari seberapa banyak peternak yang memahami dan menerapkan kembali ilmu yang sudah diterima oleh peternak bersangkutan. Sedangkan bagi peternak yang tidak memahami perlu tindaklanjut khusus, seperti melalui penyuluhan kembali dan mengajarkan langsung cara pembuatan dari dedak padi fermentasi.
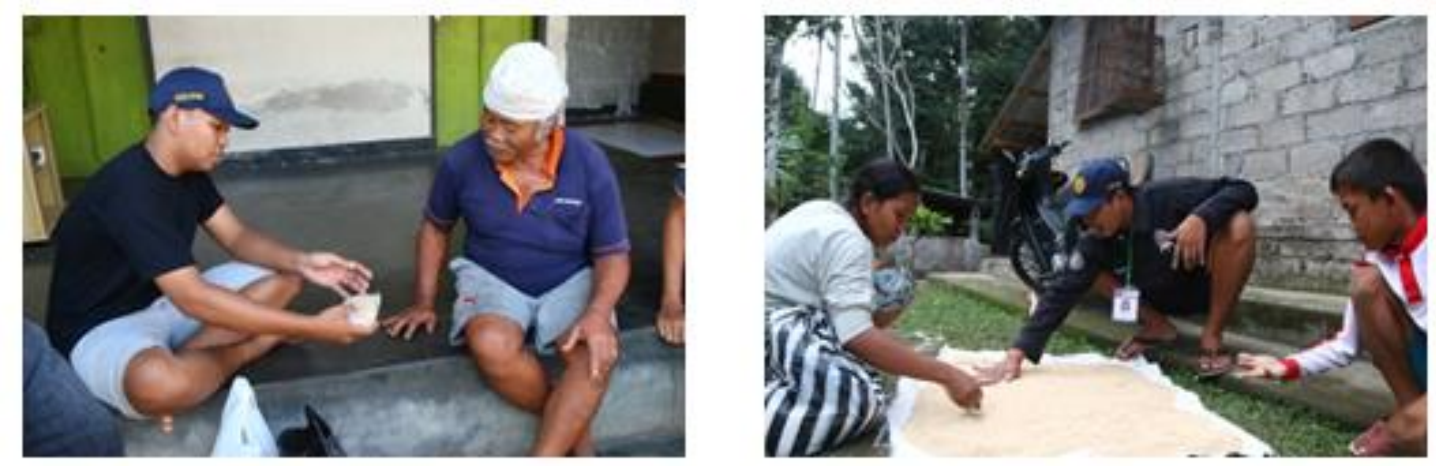

Melakukan penyuluhan secara perorangan ( kiri) dan salah satu peternak yang menerapkan teknologi fermentasi dedak padi ( kanan)

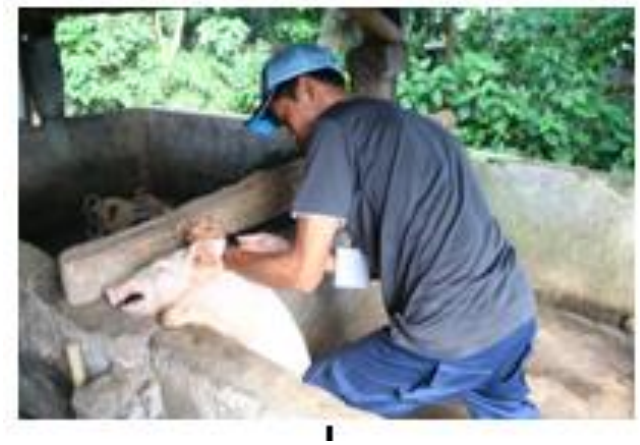

Kegiatan tambahan berupa pemberian vitamin B Kompleks kepada ternak

\section{KESIMPULAN}

Kemajuan pertanian di Desa Ayunan berbanding terbalik dengan pemanfaatan limbah pakan pertaniannya. Terutama limbah pertanian khususnya dedak padi yang tidak 
dimanfaatkan sebagai pakan ternak. Sehingga perlu adanya penyuluhan mengenai pengolahan pakan dedak padi yang dimana salah satu cara pengolahannya dengan fermentasi pakan. Dimana hasil dari penyuluhan teknologi fermentasi dedak padi di Desa Ayunan menunjukkan angka keberhasilan $85 \%$.

\section{UCAPAN TERIMAKASIH}

Penulis mengucapkan terima kasih kepada Rektor Universitas Udayana melalui Ketua LPPM UNUD yang telah memfasilitasi pengabdian kepada masyarakat ini. Penulis juga mengucapkan terima kasih kepada Kepala Perbekel Desa Ayunan beserta jajarannya, para kelian banjar di Desa Ayunan, dan rekan-rekan mahasiswa KKN PPM Universitas Udayana Desa Ayunan periode XIII Tahun 2016.

\section{DAFTAR PUSTAKA}

Sukaryana.Y.,U.Atmomarsono,V.D.Yunianto,E.Supriyatna.2011. Peningkatan Nilai Kecernaan Protein Kasar Dan Lemak Kasar Produk Fermentasi Campuran Bungkil Inti Sawit Dan Dedak Padi Pada Broiler. JTP, 1(3):167-172.

Suparta.N.2009.Penyuluhan Peternakan.Udayana University Press. Fakultas Peternakan Universitas Udayana. Denpasar.

LPPM Unud 2016, Laporan Akhir Kegiatan KKN PPM Pediode XIII Desa Ayunan, Kecamatan Abian semal Kabupaten Badung. 